\title{
Effect of an oestrogen synthesis inhibitor, 1,4,6-androstatriene-3,17-dione, on mouse embryo development in vitro
}

\author{
Jayasree Sengupta, S. K. Roy and S. K. Manchanda \\ Department of Physiology, All India Institute of Medical Sciences, New Delhi-110029, India
}

\begin{abstract}
Summary. Mouse embryos (4-8 cells) were cultured for $48 \mathrm{~h}$ in vitro in medium containing 1,4,6-androstatriene-3,17-dione (ATD). The inhibition of embryo development by ATD was overcome by oestradiol-17 $\beta$ but not by oestradiol-17 $\alpha$. Culture with ATD for the first and second $24 \mathrm{~h}$ led to normal numbers of blastocysts. The results show that preimplantation mouse embryos contain the enzymic machinery for synthesis of oestrogen.
\end{abstract}

\section{Introduction}

The development of a fertilized egg to an implanting blastocyst involves a series of structural and biochemical changes during which cellular differentiation into an inner cell mass and trophoblast occurs. Histochemical evidence of $\Delta^{5}-3 \beta$-hydroxysteroid dehydrogenase $(3 \beta$-HSD) and $17 \beta$-hydroxysteroid dehydrogenase (17 $\beta$-HSD) in mouse preimplantation embryos suggests that embryos may be able to synthesize steroids; maximum amounts are present just before implantation (S. K. Dey \& Z. Dickmann, unpublished). The conversion of $\left[{ }^{3} \mathbf{H}\right]$ testosterone to $\left[{ }^{3} \mathrm{H}\right]$ oestradiol- $17 \beta$ is also maximal in rabbit blastocysts at this time (George \& Wilson, 1978). Steroidogenesis in morulae and blastocysts may play a role in embryonic development and in the preparation of the endometrium for implantation. In the mouse, the development of morulae into blastocysts in vitro was inhibited by CI-628 citrate, an oestrogen antagonist (Sengupta, Dey \& Dickmann, 1977; Roy, 1980). The present study was undertaken to examine the effect on mouse embryos grown in culture of 1,4,6-androstatriene-3,17-dione, an inhibitor of oestrogen synthetase (aromatase) in human placental (Schwarzel, Kruggel \& Brodie, 1973) and rat ovarian (Brodie, Schwarzel \& Brodie, 1976) microsomal systems.

\section{Materials and Methods}

Random bred Swiss mice were killed on the morning of Day 3 of gestation (Day $1=$ day of finding copulatory plug at normal oestrus) to recover embryos. The embryos $(80-85 \%$ at the 8 -cell stage, the rest at the 4-cell stage) were pooled, washed in culture medium and then randomly distributed to tubes for culture for $48 \mathrm{~h}$ according to the method described by Whitten (1971). The tubes contained the following substances.

Group 1: $50 \mu$ l ethanol saline $\left(0.9 \% \mathrm{NaCl}\right.$ solution; $1.4 \times 10^{-2} \mathrm{mmol}$ ethanol) and $4 \mu \mathrm{l}$ propylene glycol $\left(5.2 \times 10^{-2} \mathrm{mmol}\right)$.

Group 2: $4 \mu \mathrm{g} \mathrm{1,4,6-androstatriene-3,17-dione} \mathrm{(ATD:} \mathrm{Research} \mathrm{Plus} \mathrm{steroids,} \mathrm{Denville,} \mathrm{New}$ Jersey, U.S.A.; $3.5 \times 10^{-2} \mathrm{mmol}$ ) in $4 \mu \mathrm{l}$ propylene glycol and $50 \mu \mathrm{l}$ ethanol-saline. 
Group 3: $4 \mu \mathrm{g}$ ATD and $1 \mu \mathrm{g}$ oestradiol-17 $\beta$ (Sigma, St Louis, Missouri, U.S.A.; $3.4 \times 10^{-3}$ $\mathrm{mmol}$ ) in $50 \mu$ l ethanol-saline.

Group 4: $4 \mu \mathrm{g}$ ATD and $1 \mu \mathrm{g}$ oestradiol-17 $\alpha$ (Sigma; $3.4 \times 10^{-3} \mathrm{mmol}$ ) in $50 \mu \mathrm{l}$ ethanol-saline.

Group 5: $4 \mu \mathrm{g}$ ATD for the first $24 \mathrm{~h}$ of culture and then no steroid for the second $24 \mathrm{~h}$ of culture.

Group 6: $4 \mu \mathrm{g}$ ATD during the second $24 \mathrm{~h}$ of the culture period.

In Groups 5 and 6, embryos were recovered after culture for $24 \mathrm{~h}$, washed in fresh medium and briefly examined under a stereo-zoom microscope to check their development, and then re-cultured in fresh medium.

In each group, cultures were repeated several times (see Table 1) on several days and the development of expanded blastocysts without any apparent signs of abnormality was taken to indicate normal embryogenesis.

In preliminary experiments $1 \mu \mathrm{g}$ oestradiol $-17 \beta / \mathrm{ml}$ was the optimum steroid concentration required to overcome the inhibitory effect of ATD on embryonic development in vitro. ATD at a concentration lower than $4 \mu \mathrm{g} / \mathrm{ml}$ was unable to exert any effect on mouse embryo development.

All results were subjected to a statistical test of proportion (Downie \& Heath, 1970).

\section{Results}

The results for Groups 1 and 3 were similar in that oestradiol-17 $\beta$ overcame the inhibitory influence of ATD (Table 1). However, addition of oestradiol-17 $\alpha$ failed to maintain embryonic development. In Groups 2 and 4 the embryos that did not develop were arrested at the morula stage and showed no signs of degeneration. The treatments for Groups 5 and 6 yielded similar high proportions of developing blastocysts (Table 2).

Table 1. Effects of 1,4,6-androstatriene-3,17-dione (ATD) and oestrogens on mouse embryo development in vitro

\begin{tabular}{|c|c|c|c|c|c|}
\hline Group & $\begin{array}{l}\text { Steroids in } \\
\text { culture medium }\end{array}$ & Steroid dose $/ \mathrm{ml}$ & $\begin{array}{c}\text { No. of } \\
\text { 4-8-cell embryos } \\
\text { cultured } \\
\text { (no. of replicates) }\end{array}$ & $\begin{array}{c}\text { No. of blastocysts } \\
\text { developed after } \\
48 \mathrm{~h}(\%)\end{array}$ & $\begin{array}{l}\text { No. of } \\
\text { degenerating } \\
\text { embryos }\end{array}$ \\
\hline 1 & - & - & $96(10)$ & $80(83)$ & 16 \\
\hline 2 & ATD & $4 \mu \mathrm{g}$ & $79(9)$ & $8(10)$ & 71 \\
\hline 3 & ATD + oestradiol- $17 \beta$ & $4 \mu \mathrm{g}+1 \mu \mathrm{g}$ & $96(9)$ & $73(76)$ & 23 \\
\hline 4 & ATD + oestradiol- $17 \alpha$ & $4 \mu \mathrm{g}+1 \mu \mathrm{g}$ & $82(6)$ & $7(8)$ & 75 \\
\hline
\end{tabular}

Propylene glycol (the solvent of ATD) and $50 \mu$ ethanol (the solvent for oestrogens) were added to the medium in all groups.

Group 1 versus Group 2 and Group 2 versus Group 3: $P<0.001$; Group 1 versus Group 4: $P<0.05$ (proportion tests, Z).

Table 2. Effect of ATD given for only $24 \mathrm{~h}$ during the $48 \mathrm{~h}$ culture period on mouse embryo development

\begin{tabular}{cccccccc}
\hline & \multicolumn{4}{c}{ First 24h } & & \multicolumn{3}{c}{ Second 24h } \\
\cline { 2 - 4 } Group & $\begin{array}{c}\text { ATD } \\
(\mu \mathrm{g} / \mathrm{ml})\end{array}$ & $\begin{array}{c}\text { No. of embryos } \\
\text { cultured }\end{array}$ & $\begin{array}{c}\text { No. of morulac } \\
\text { developed }\end{array}$ & $\begin{array}{c}\text { ATD } \\
(\mu \mathrm{g} / \mathrm{ml})\end{array}$ & $\begin{array}{c}\text { No. of morulae } \\
\text { cultured }\end{array}$ & $\begin{array}{c}\text { No. of } \\
\text { blastocysts } \\
\text { developed }(\%)\end{array}$ \\
\hline 5 & 4 & 73 & 73 & - & 73 & $58(73)$ \\
6 & - & 63 & 63 & 4 & 63 & $53(84)$ \\
\hline
\end{tabular}




\section{Discussion}

Culture of mouse embryos with ATD inhibited their development and differentiation. We suggest that ATD interferes with endogenous oestrogen synthesis because the inhibitory effect of ATD on blastocyst development was reversed completely by exogenous administration of oestradiol-17 $\beta$. Barker \& Anderson (1968) observed that oestradiol-17 $\alpha$ can bind to chromatin of uterine cells, but can not evoke the characteristic responses of hyperaemia and vasodilation normally observed with oestradiol-17 $\beta$. In the present study we found that oestradiol-17 $\alpha$ was also unable to mimic the action of oestradiol- $17 \beta$ on embryonic development.

ATD is an androgenic compound and it could be argued that its deleterious effect on embryos was due to an excessive amount of this steroid. Although ATD has no significant hormonal activity when tested in a conventional bioassay, Christensen \& Clemens (1975) noted some androgenic effect in the very sensitive penile spines of the immature rat. In the present study it is unlikely that inhibition is due to any non-specific toxicity or androgenic effect because oestradiol-17 $\beta$ was effective in nullifying the action of ATD on preimplantation embryos. In rats ATD has an antifertility effect by preventing mating and ovulation and this can be reversed by treatment with exogenous oestrogen (Brodie, Wu, Marsh \& Brodie, 1979). Blastocyst formation in Group 5 could have been due to oestrogen biosynthesis by newly formed enzymes or because of the breakdown of ATD into its metabolites which no longer bind to aromatase. In Group 6 the results are explicable if oestrogen is produced in pre-morula stage embryos. Steroidogenic enzymes have been histochemically demonstrated in 4-8-cell embryos (S. K. Dey \& Z. Dickmann, unpublished) and oestrogen synthesized in embryos during the pre- or post-morula stages seems to be sufficient for preimplantation embryo development. When this was blocked by exposure of eggs to ATD for $48 \mathrm{~h}$, morula to blastocyst transformation was prevented. These findings suggest that the availability of oestrogen in blastomeres is essential for morula to blastocyst transition.

Rabbit blastocysts are reported to synthesize oestradiol-17ß (George \& Wilson, 1978; Gadsby, Heap \& Burton, 1980) but no such data are available for the mouse blastocyst. The present study has shown that the mouse preimplantation embryo contains the enzymic machinery for synthesis of oestrogen and that oestrogen is involved in the morula to blastocyst transformation in vitro.

This work was supported by funds from the Indian Council of Medical Research and the Family Planning Foundation of India.

\section{References}

Barker, K.L. \& Anderson, J.M. (1968) Displacement of estradiol-17 $\beta$ from the uterus by estradiol-17 $\alpha$ : effect on template capacity of uterine chromatin. Endocrinology 83, 585-591.

Brodie, A.M.H., Schwarzel, W.C. \& Brodie, H.J. (1976) Studies on the mechanism of estrogen biosynthesis in the rat ovary-1. J. Steroid Biochem. 7, 787-793.

Brodie, A.M.H., Wu, J.T., Marsh, D.A. \& Brodie, H.J. (1979) Antifertility effects of an aromatase inhibitor, 1,4,6-androstatriene-3,17-dione. Endocrinology 104, $118-121$.

Christensen, L.W. \& Clemens, L.G. (1975) Blockade of testosterone induced mounting behavior in the male rat with intracranial application of the aromatization inhibitor, androst-1,4,6-triene-3,17-dione. Endocrinology 97, 1545-1551.
Downie, N.M. \& Heath, R.W. (1970) Basic Statistical Methods, 3rd edn, pp. 188-195, Harper \& Row, New York.

Gadsby, J.E., Heap, R.B. \& Burton, R.D. (1980) Oestrogen production by blastocyst and early embryonic tissues of various species. J. Reprod. Fert. 60, 409-417.

George, F.W. \& Wilson, J.D. (1978) Estrogen formation in the early rabbit embryo. Science, N.Y. 199, 200201.

Roy, S.K. (1980) $A$ study of events in early gestation and control of implantation. Ph.D. thesis, All India Institute of Medical Sciences, New Dehli.

Schwarzel, W.C., Kruggel, W.G. \& Brodie, H.J. (1973) Studies on the mechanism of estrogen biosynthesis VIII. The development of inhibitors of the enzyme 
system in human placenta. Endocrinology 92, 866880.

Sengupta, J., Dey, S.K. \& Dickmann, Z. (1977) Evidence that "embryonic estrogen" is a factor which controls the development of the mouse preimplantation embryo. Steroids 29, 363-369.
Whitten, W.K. (1971) Nutrient requirements for the culture of preimplantation embryos in vitro. $A d v$. Biosci. 6, 129-141.

Received 23 September 1981 